PEDAGOGIEK

www.pedagogiek-online.nl

Uitgave: Amsterdam University Press

\title{
Zijn de voordelen van tweetaligheid voor alle tweetalige kinderen even groot?
}

Een exploratief onderzoek naar de leerkrachtwaardering van de thuistaal van leerlingen en de invloed daarvan op de ontwikkeling van hun executieve functies.

Claire Goriot, Joep Bakker, Eddie Denessen \& Mienke Droop

PED 36 (2): 135-153

DOI: 10.5117/PED2016.2.GORI

\begin{abstract}
Benefits of being bilingual? The relationship between pupils' perceptions of teachers' appreciation of their home language and executive functioning

We aimed to investigate whether bilingual pupils' perceptions of their teachers' appreciation of their Home Language $(\mathrm{HL})$ were of influence on bilingual cognitive advantages. We examined whether Dutch bilingual primary school pupils who speak either German or Turkish at home differed in perceptions of their teacher's appreciation of their $\mathrm{HL}$, and whether these differences could explain differences between the two groups in executive functioning. Executive functioning was measured through computer tasks, and perceived $\mathrm{HL}$ appreciation through orally administered questionnaires. The relationship between the two was assessed with regression analyses. German-Dutch pupils perceived more appreciation of their home language from their teacher than Turkish-Dutch pupils did. This difference partly explained differences in executive functioning. Besides, we replicated bilingual advantages in nonverbal working memory and switching, but not in verbal working memory or inhibition. This study demonstrates that bilingual advantages cannot be dissociated from the influence of the sociolinguistic context of the classroom. Thereby, it stresses the importance of culturally responsive teaching.
\end{abstract}

Keywords: bilingualism, executive functioning, sociolinguistic context, culturally responsive teaching, primary school 


\section{Inleiding}

De Nederlandse maatschappij kent een grote verscheidenheid aan culturen en, daarmee samenhangend, een minstens zo grote diversiteit aan talen. Dat bedenkend is het niet verwonderlijk dat het merendeel van de Nederlandse bevolking meer dan één taal zegt te spreken. Een grote groep tweetaligen wordt gevormd door inwoners die één van de talen spreken die arbeidsmigranten in de jaren vijftig en zestig van de vorige eeuw het land binnenbrachten, meestal Turks of Marokkaans-Arabisch. Een andere substantiële groep wordt gevormd door inwoners die een taal afkomstig uit één van de buurlanden spreken, veelal Engels of Duits. Eerder onderzoek heeft uitgewezen dat tweetaligen, vergeleken met eentaligen, in een aantal opzichten in het voordeel zijn. In dit verband denken we niet in de eerste plaats aan de economische voordelen die in een globaliserende wereld met tweetaligheid gepaard zouden gaan. Belangrijker wellicht zijn de voordelen die tweetaligheid in het cognitieve domein met zich mee brengt (Adesope, Lavin, Thompson, \& Ungerleider, 2010; Bialystok, 2009). De vraag is echter of de voordelen zich bij alle tweetaligen in gelijke mate voordoen, of dat die afhankelijk zijn van omgevingsfactoren, zoals de sociolinguïstische context. In de exploratieve studie waarover hier wordt gerapporteerd, staan de percepties van tweetalige basisschoolleerlingen van de mate waarin hun thuistaal door hun leerkracht wordt gewaardeerd centraal. Met het inzicht daarin hopen we een antwoord te vinden op de vraag hoe contextuele factoren van invloed zijn op de veronderstelde cognitieve voordelen van tweetaligheid.

\section{Cognitieve voordelen van tweetaligheid}

De cognitieve voordelen van tweetaligheid lijken voornamelijk betrekking te hebben op de executieve functies - in het vervolg als EF aangeduid: een overkoepelende term voor meerdere aan elkaar gerelateerde processen die gezamenlijk voorzien in de uitvoering van en de reflectie op doelgericht gedrag (St Clair-Thompson \& Gathercole, 2006). EF zijn daarmee, onder andere, belangrijk voor de schoolprestaties (Blair \& Peters Razza, 2007; St Clair-Thompson \& Gathercole, 2006), en, zoals Moffitt en collega's (2011) dat noemen, voor een welvarend leven in de volwassenheid. Er wordt veelal aangenomen dat EF drie kernprocessen behelzen (Garon, Bryson, \& Smith, 2008; Miyake et al., 200o): (1) inhibitie: de mogelijkheid om impulsieve reacties te onderdrukken en meer doordacht te reageren; (2) switching (ook wel shifting genoemd) dat beschreven kan worden als de flexibiliteit om zich aan te passen aan verschillende regels en zich te confor- 
meren aan veranderende omstandigheden; (3) het werkgeheugen dat verwijst naar het proces waardoor informatie onthouden en gemanipuleerd kan worden. Het werkgeheugen wordt doorgaans onderscheiden in het verbaal en het non-verbaal werkgeheugen (Diamond, 2013).

EF ontwikkelen zich voornamelijk tijdens de kindertijd. Kunnen peuters al informatie onthouden, het vermogen deze informatie te manipuleren ontwikkelt zich echter pas later, evenals inhibitie en switching. Pas tijdens de volwassenheid zijn die processen volledig gerijpt (Diamond, 2013). De ontwikkeling van EF kan positief beïnvloed worden door allerhande factoren, zoals het sociaal milieu. Het is daarom belangrijk om in onderzoek niet aan deze factor voorbij te gaan. Daarnaast kunnen EF gestimuleerd worden door speciale computer- of educatieve programma's, maar ook door het spreken van een tweede taal (Diamond, 2013). In deze studie wordt onderzocht of de mate waarin tweetaligheid binnen de schoolcontext gewaardeerd wordt, invloed heeft op de EF.

De vraag of tweetaligheid gunstig uitwerkt op EF is uitgebreid onderzocht. Hoewel in sommige onderzoeken (zie bijvoorbeeld Antón et al., 2014) geen voordelen gevonden worden, zijn er veel studies die illustreren dat tweetalige kinderen in vergelijking met hun eentalige leeftijdsgenootjes, een voorsprong vertonen in switching, inhibitie (zie bijvoorbeeld Bialystok \& Viswanathan, 2009) en werkgeheugen (zie bijvoorbeeld Morales, Calvo, \& Bialystok, 2013). Ofschoon er nog discussie bestaat over de precieze werking ervan, bestaat er in het algemeen consensus over het mechanisme dat deze voordelen doet ontstaan. Volgens Green (1998) zijn de twee talen waarin iemand vaardig is, tegelijkertijd actief. Omdat slechts één taal tegelijkertijd gebruikt kan worden, moet de andere worden onderdrukt. Dit automatische proces doet een beroep op de EF, die derhalve versterkt zouden worden.

Hoewel voordelen in EF voor tweetaligen regelmatig in de onderzoeksliteratuur aangetoond zijn (Adesope et al., 2010; Bialystok, 2009), is het de vraag of de voordelen voor alle tweetaligen even groot zijn. Bekend is dat die onder meer afhankelijk zijn van de leeftijd waarop de tweede taal is geleerd alsmede van de vaardigheid in beide talen. Verondersteld mag worden dat ook andere, meer omgevingsafhankelijke aspecten, zoals de sociolinguïstische context waarin de tweetaligen zich bevinden, van invloed zijn. De sociolinguïstische context lijkt bepalend voor de mate waarin talen gewaardeerd worden, en daarmee voor de status die een bepaalde taal toegedicht krijgt (Appel \& Muysken, 2005). Dat sommige talen meer gewaardeerd worden dan andere is doorgaans gerelateerd aan de sociale status van de maatschappelijke groep die met de betreffende taal geassocieerd wordt. Talen die gesproken worden door etnische minderheidsgroe- 
peringen krijgen een relatief lage status toegedicht, omdat deze in verband gebracht worden met groeperingen waarvan de leden, gemiddeld genomen, een laag opleidingsniveau hebben, slecht betaald werk verrichten en vaker werkloos zijn (Van Gaalen \& De Vos, 2011).

De sociolinguïstische context, en daarmee de status van talen, wordt mede beïnvloed door het overheidsbeleid (Appel \& Muysken, 2005). De Nederlandse overheid lijkt een ambivalente houding jegens tweetaligheid in te nemen. Enerzijds bevordert zij het spreken van verschillende talen, bijvoorbeeld door het stimuleren van vroeg vreemdetalenonderwijs - het betreft dan overigens altijd westerse talen (Kuiken \& Van der Linden, 2014), anderzijds wordt het spreken van bepaalde talen ontmoedigd. Leerlingen die een etnische minderheidsachtergrond hebben worden vaak gedwongen Nederlands te spreken in plaats van hun thuistaal, omdat het spreken van de thuistaal integratie in de maatschappij zou hinderen (Agirdag, Jordens, \& Van Houtte, 2014; Kuiken \& Van der Linden, 2014). Bovendien, zo wordt door de overheid aangenomen, zou het spreken van de thuistaal ten koste van het Nederlands gaan, hetgeen weer zou resulteren in een taalachterstand in het Nederlands (Leseman, 2000). Ondanks een gebrek aan wetenschappelijk bewijs voor deze aanname (Atwill, Blanchard, Christie, Gorin, \& García, 2010; Eisenchlas, Schalley, \& Guillemin, 2013), zijn mede om die reden onderwijsfaciliteiten zoals het Onderwijs in Eigen Taal en Cultuur afgeschaft (Extra \& Yağmur, 2004; Kuiken \& Van der Linden, 2014).

Hoewel in recentelijk onderzoek aangetoond werd dat leerkrachten vaak voorstander zijn van het beleid dat de overheid voert en het spreken van de thuistaal eerder weren dan toestaan (Pulinx, Van Avermaet, \& Agirdag, 2015), kunnen leerkrachten variëren in hun houding ten aanzien van het taalgebruik op school. Door op school het gebruik van de thuistaal van leerlingen zo niet te stimuleren dan toch in elk geval te tolereren, kunnen zij bijdragen aan de mate waarin leerlingen tweetalig zijn. Door een stimulerende sociolinguïstische context te creëren, zouden zij zodoende de cognitieve voordelen van tweetaligheid kunnen bevorderen.

\section{Cultuurresponsieve leerkrachten}

Leerkrachten kunnen de manier waarop zij communiceren en instructie geven aanpassen aan specifieke kenmerken van de cultuur van de leerlingen in hun klas (Gay, 2002). Cultuurresponsieve leerkrachten kunnen bijvoorbeeld tijdens hun lessen gebruik maken van de thuistaal van leerlingen (Chun \& Dickson, 2011), of leerlingen complimenteren omdat zij een tweede taal beheersen (Lee \& Oxelson, 2011). Verkleinen ze daarmee de kloof tussen de thuis- en de schoolcultuur waardoor het leerproces effectiever kan ver- 
lopen (Brown, 2007), ontegenzeggelijk staat het ruimte geven aan de eigen (thuis)taal borg voor gevoelens van veiligheid en welbevinden van de leerling (Gay, 2002). Leerlingen kunnen zich bewust zijn van de mate waarin hun leerkracht hun thuistaal waardeert. Dat blijkt onder meer uit onderzoek van Agirdag (2010). Hij interviewde Turks-Vlaamse middelbare scholieren. $\mathrm{Zij}$ gaven aan het gevoel te hebben dat leerkrachten etnische minderheidstalen minder waardeerden dan westerse talen. Zo mochten leerlingen bijvoorbeeld wel Engelse kranten lezen, maar geen Turkse. Hoewel onderzoek heeft aangetoond dat leerlingen weet hebben van de mate waarin verschillende talen gewaardeerd worden, is er slechts weinig onderzoek gedaan naar de effecten van deze percepties op hun cognitie. Er mag echter worden aangenomen dat wanneer leerkrachten hun leerlingen dwingen om af te zien van het gebruik van de thuistaal en hen verplichten alleen Nederlands te bezigen, zij de mogelijkheden inperken om tussen talen te wisselen. Het gevolg is dat aan belangrijke voorwaarden om EF te ontwikkelen niet voldaan wordt (Carlson \& Meltzoff, 2008; Green, 1998).

\section{Huidig onderzoek}

In dit onderzoek staan tweetalige kinderen centraal die, naast Nederlands, één van de twee meest gesproken talen in Nederland spreken, namelijk Turks of Duits. Meer concreet is de onderzoeksvraag in welke mate tweetalige leerlingen met deze verschillende thuistalen het gevoel hebben dat hun taal door hun leerkracht gewaardeerd wordt, en of deze ervaringen invloed hebben op hun EF, in het bijzonder op de kernprocessen inhibitie, switching en werkgeheugen. Het onderzoeksdoel is drieledig. Ten eerste wordt getracht opnieuw aan te tonen dat tweetalige kinderen voordelen genieten in EF. Ten tweede wordt onderzocht of deze voordelen gelijk zijn voor leerlingen die vaardig zijn in verschillende thuistalen en, ten derde, of hun EF beïnvloed worden door de percepties die zij hebben van de mate waarin leerkrachten hun thuistaal waarderen. Verwacht wordt dat tweetalige leerlingen die ervaren dat hun thuistaal minder gewaardeerd wordt, minder goed ontwikkelde EF hebben dan tweetalige leerlingen die hun thuistaal meer gewaardeerd weten.

\section{Methode}

\section{Deelnemers}

Aan het onderzoek participeerden 71 kinderen en hun ouders; ze woonden verspreid over Nederland. Werving vond plaats via websites voor inwoners 
met een Duitse of Turkse achtergrond in Nederland, alsmede door gericht scholen aan te schrijven. Om te voorkomen dat kinderen in dezelfde klas zaten en daarmee afhankelijkheid van data niet uit te sluiten viel, werd slechts één leerling per leerkracht getest. Door mondeling afgenomen vragenlijsten bevestigden ouders dat hun kinderen exclusief vaardig waren in het Nederlands, of dat zij zowel het Nederlands alsmede het Duits óf Turks beheersten. Informatie over het opleidingsniveau van de ouders is gebruikt als maat voor sociaal-economische status (SES; zie Tabel 1). Voor de ouders van twee Turks-Nederlandse kinderen ontbrak het aan informatie hierover. SES bleek niet gelijk verdeeld over de groepen $\left(\chi^{2}(4)=20.47, p<.001\right)$; Turks-Nederlandse kinderen waren in het algemeen afkomstig uit lagere sociaal-economische milieus dan kinderen uit de twee andere groepen. De gemiddelde leeftijd van de drie groepen (eentaligen, Nederlands-Duits tweetaligen en Nederlands-Turks tweetaligen) bleek niet significant te verschillen $(F(2,68)=2.25, p=.113)$.

\section{Executieve functies}

Om het inhibitievermogen van de kinderen vast te stellen, werd hen de Flanker Fish-taak van Diamond, Barnett, Thomas en Munro (2007) voorgelegd. Deze taak bestond uit drie afzonderlijke blokken waarin getekende vissen werden getoond. In het eerste blok waren die blauw, in het tweede roze, in het derde afwisselend blauw en roze. Bij het eerste blok kregen de kinderen de instructie uitsluitend op de middelste vis, de stimulus, te letten, bij het tweede dienden ze zich te concentreren op de andere vissen. De middelste vis kon naar rechts of naar links 'zwemmen' (het beeld was statisch: een naar een bepaale richting kijkende vis werd geacht in die betreffende richting te zwemmen). De overige konden dezelfde kant op zwemmen als de middelste vis, maar konden ook de andere kant of omlaag zwemmen. In het eerste blok dienden de buitenste vissen als afleiders, in het tweede had de middelste vis die functie. Om de vis(sen) te kunnen 'voeren' dienden de kinderen op een toets aan de linker of rechter kant van het toetsenbord te drukken, afhankelijk van de richting waarin de vis(sen) zwom(men). Bij de eerste twee blokken mochten de kinderen vier maal oefenen, alvorens de experimentele trials van start gingen, het derde en laatste ging zonder oefening van start. Bij de twee eerste blokken waren er 16 experimentele trials, bij het laatste 44 . Gedurende alle drie de blokken hadden kinderen 1500 milliseconden om een respons (voeren) te geven. Alle incorrecte responsen en alle responsen beneden 200 of boven 1500 milliseconden werden verwijderd (19.3\% in totaal). Vervolgens werd de score voor inhibitie berekend als het verschil in gemiddelde reactietijd 
tussen het gemixte blok waarin blauwe en roze vissen afwisselend werden getoond en de gemiddelde reactietijd van het blok waarin slechts roze vissen te zien waren. De data van zeven kinderen (één eentalig kind en zes Turks-Nederlandse tweetalige kinderen) ontbraken of werden verwijderd als gevolg van technische problemen of omdat de kinderen voornamelijk incorrecte responses gaven.

Tabel 1 Descriptieve statistieken per groep

\begin{tabular}{|c|c|c|c|c|}
\hline & & Nederlands & $\begin{array}{c}\text { Nederlands- } \\
\text { Duits }\end{array}$ & $\begin{array}{c}\text { Nederlands- } \\
\text { Turks } \\
\end{array}$ \\
\hline \multirow[t]{2}{*}{ Geslacht } & Jongens (N) & 13 & 17 & 9 \\
\hline & Meisjes (N) & 10 & 8 & 14 \\
\hline Leeftijd & $M(S D)$ & $8.99(0.68)$ & $9.49(0.75)$ & $9.11(1.10)$ \\
\hline \multirow[t]{3}{*}{ SES } & Laag $(N)$ & 0 & 0 & 3 \\
\hline & Midden (N) & 4 & 0 & 8 \\
\hline & Hoog $(N)$ & 19 & 25 & 10 \\
\hline $\begin{array}{l}\text { \% gebruik Nederlands } \\
\text { (beoordeling kind) }\end{array}$ & $M(S D)$ & $91.78(3.32)$ & $62.30(14.96)$ & $53.31(12.44)$ \\
\hline $\begin{array}{l}\text { \% gebruik thuistaal } \\
\text { (beoordeling kind) }\end{array}$ & $M(S D)$ & - & $34.26(14.03)$ & $43.26(12.60)$ \\
\hline $\begin{array}{l}\text { \% gebruik Nederlands } \\
\text { (beoordeling ouder) }\end{array}$ & $M(S D)$ & $89.69(3.70)$ & $57.17(12.51)$ & $54.38(15.38)$ \\
\hline $\begin{array}{l}\text { \% gebruik thuistaal } \\
\text { (beoordeling ouder) }\end{array}$ & $M(S D)$ & - & 40.75 (15.38) & $43.60(14.54)$ \\
\hline \multirow[t]{3}{*}{ Non-verbaal werkgeheugen } & $N$ & 23 & 25 & 23 \\
\hline & $M(S D)$ & $4.65(0.93)$ & $5.32(0.90)$ & $5.17(1.30)$ \\
\hline & Min.-Max. & $3-6$ & 4-7 & $3-9$ \\
\hline \multirow[t]{3}{*}{ Verbaal werkgeheugen } & $N$ & 23 & 25 & 23 \\
\hline & $M(S D)$ & $4.00(1.17)$ & $4.96(1.40)$ & $3.87(1.01)$ \\
\hline & Min.-Max. & $2-7$ & $3-7$ & $2-5$ \\
\hline \multirow[t]{3}{*}{ Switching } & N & 23 & 25 & 23 \\
\hline & $M(S D)$ & 77.53 (68.44) & $29.02(66.25)$ & $55.65(62.31)$ \\
\hline & Min.-Max. & $-49.32-231.83$ & $-113.79-179.06$ & $-58.32-180.06$ \\
\hline \multirow[t]{3}{*}{ Inhibitie } & N & 22 & 25 & 17 \\
\hline & $M(S D)$ & 150.07 (131.64) & $200.09(128.83)$ & $151.39(137.00)$ \\
\hline & Min.-Max. & $-74.08-451.19$ & $-81.71-453.81$ & $-109.71-495.27$ \\
\hline Thuistaaltolerantie & $M(S D)$ & - & $1.86(0.25)$ & $1.40(0.33)$ \\
\hline Thuistaalappreciatie & $M(S D)$ & - & $1.62(0.32)$ & $1.38(0.27)$ \\
\hline Stimuleren Nederlands & $M(S D)$ & - & $1.33(0.26)$ & $1.51(0.28)$ \\
\hline \multirow[t]{2}{*}{ Raven } & $M(S D)$ & $29.61(3.13)$ & $32.44(2.47)$ & $27.91(4.09)$ \\
\hline & Min.-Max. & $24-34$ & $25-36$ & $18-35$ \\
\hline
\end{tabular}


Het vermogen tot switching werd vastgesteld met behulp van een versie van de Faces-taak van Bialystok en Viswanathan (2009). De kinderen kregen een schematisch weergegeven gezicht te zien, met aan weerszijden een vierkant. Vervolgens kleurden de ogen in het gezicht rood of groen, waarna het gezicht verdween en alleen de vierkanten overbleven. Een asterisk verscheen kort (500 ms) in één van de vierkanten. Kinderen dienden binnen $1500 \mathrm{~ms}$ op een knop op het toetsenbord te drukken aan dezelfde kant als de asterisk wanneer de ogen groen waren, en aan de tegenovergestelde kant wanneer die rood oplichtten. De taak was verdeeld in vier blokken waarin de ogen slechts één kleur aannamen en vier blokken waarin de ogen afwisselend rood en groen waren. Elk blok bestond uit 24 trials. De helft van de blokken bestond uit trials waarin de ogen vooruit keken, de andere helft uit trials waarin die naar links of rechts gericht waren. Voorafgaand aan de blokken waarin de ogen vooruit dan wel opzij keken, was er een oefenblok van 8 trials. Dezelfde procedure als voor de Flanker Fishtaak werd gevolgd om incorrecte en afwijkende responsen $(23.6 \%$ in totaal) te verwijderen. De switchingscore werd bepaald door de gemiddelde reactietijd bij de gemixte blokken en de blokken waarin de ogen slechts één kleur aannamen met elkaar te vergelijken.

Het non-verbaal werkgeheugen werd vastgesteld met de Corsi Block Tapping-taak (Vandierendonck, Kemps, Fatame, \& Szmalec, 2004). Deze toets bestaat uit negen blauwe blokken die willekeurig over een zwart scherm verdeeld zijn. De blokken veranderden gedurende één seconde van blauw naar geel. Kinderen dienden op de blokken te klikken in dezelfde volgorde waarin deze van kleur veranderd waren. De taak begon met een reeks van twee blokken. Na ten minste één goed antwoord in twee achtereenvolgende reeksen van dezelfde lengte, nam de reeks met één blok toe, tot een maximum van negen blokken. De taak werd afgebroken wanneer twee reeksen van dezelfde lengte fout herinnerd werden. De uiteindelijke maat voor non-verbaal werkgeheugen was de lengte van de reeks die als laatste goed onthouden werd.

Het verbaal werkgeheugen werd in beeld gebracht door de Backward Digit Span-taak van Kort et al. (2005). Deze bestaat uit een reeks getallen die mondeling aan het kind gepresenteerd wordt. Het kind werd geïnstrueerd deze getallen achterwaarts te herhalen. De taak begon met een reeks van twee getallen. Na elke twee reeksen werd hier een getal aan toegevoegd. De taak werd afgebroken wanneer twee reeksen van dezelfde lengte onjuist werden herhaald. De totaalscore was het aantal correct herhaalde reeksen, en kon variëren van o tot 18 . 


\section{Sociolinguistische context}

Voor het in beeld brengen van de Leerlingpercepties van de leerkrachtwaardering van de thuistaal werd een vragenlijst ontwikkeld, bestaande uit 11 stellingen die gedeeltelijk gebaseerd waren op bestaande vragenlijsten (Chun \& Dickson, 2010; Lee \& Oxelson, 2006), maar voor Nederlandse basisschoolleerlingen aangepast werden. In Tabel 2 zijn de items van deze vragenlijst opgenomen. Om herhaaldelijke keuze voor een neutrale antwoordcategorie te vermijden, konden kinderen per stelling aangeven of deze waar of niet waar was. De gemiddelde score kon liggen tussen 1 en 2. Een hogere score betekende dat kinderen positiever waren over de mate waarin hun leerkracht hun thuistaal waardeerde.

Om inzicht te verkrijgen in de aspecten van thuistaalwaardering die door deze vragenlijst gemeten werden, werd een exploratieve factoranalyse (met varimaxrotatie) uitgevoerd. De screeplot wees op drie dimensies. Op grond van de ladingen konden deze als volgt worden geïnterpreteerd: tolerantie van de thuistaal, appreciatie van de thuistaal, en stimuleren van het Nederlands. Eén item bleek bij geen enkele factor onder te brengen en werd daarom uit de analyse verwijderd. De uiteindelijke factorladingen, gepresenteerd in Tabel 2, representeren samen $58.1 \%$ van de itemvariantie. 'Tolerantie van de thuistaal' bestond uit vier items (Cronbachs alphacoëfficiënt was .79). 'Appreciatie van de thuistaal' en 'stimuleren van het Nederlands' bestonden elk uit drie items (Cronbachs alphacoëfficiënten waren .43 en .56 respectievelijk). Voor elke dimensie werd een score berekend door de scores op elk van de items behorende tot deze dimensie te middelen. 'Stimuleren van het Nederlands' was negatief en statistisch significant gerelateerd aan 'tolerantie van de thuistaal' $(r=-.35, p=.015)$, maar niet aan 'waardering van de thuistaal' $(r=-.06, p>.05)$. De twee laatste dimensies waren positief, hoewel niet statistisch significant gerelateerd $(r$ $=.27, p>.05)$.

\section{Intelligentie}

Ruwe scores op de Raven's Coloured Progressive Matrices (Raven, Court, \& Raven, 1990) werden gehanteerd om inzicht te krijgen in groepsverschillen in non-verbale intelligentie. Kinderen kregen 36 patronen te zien, elk met een missend stuk. Het passende stuk moest steeds gekozen worden uit zes alternatieven. De totaalscore kwam overeen met het totale aantal correcte items. 


\section{Procedure}

Alle kinderen werden individueel getest in een rustige ruimte in hun thuisomgeving $(N=62)$ of, wanneer werving via school had plaatsgevonden, op school $(N=9)$. De taken werden in een vaste volgorde gepresenteerd. De Flanker Fish taak was geprogrammeerd in Presentation (Neurobehavioral Systems, Inc.) en de Faces and Corsi Block Tapping-taak in Inquisit (Millisecond Software). Er werd gestart met de Flanker Fish-taak, gevolgd door de Faces-taak, de Corsi Block Tapping-taak, de Backward Digit Span-taak en ten slotte de Raven-test. Daarna werd de vragenlijst over het gebruik van verschillende talen en, in het geval van tweetalige leerlingen, over hun percepties van de leerkrachtwaardering van hun thuistaal, mondeling afgenomen. Afname gebeurde in het Nederlands tijdens één sessie van ongeveer 60 minuten. Kinderen kregen een cadeautje als dank voor deelname. Ouders werden gevraagd een vragenlijst in te vullen over de verschillende talen die hun kind gebruikte. Op aanvraag konden zij een vragenlijst krijgen die was vertaald in hun thuistaal.

Tabel 2 Factorladingen op de vragenlijst over leerlingpercepties van de leerkrachtwaardering van de thuistaal $(N=48)$

\begin{tabular}{|c|c|c|c|}
\hline & \multicolumn{3}{|c|}{ Factor } \\
\hline & $\begin{array}{l}\text { Tolerantie } \\
\text { thuistaal }\end{array}$ & $\begin{array}{l}\text { Appreciatie } \\
\text { thuistaal }\end{array}$ & $\begin{array}{l}\text { Stimuleren } \\
\text { Nederlands }\end{array}$ \\
\hline $\begin{array}{l}\text { 3. Ik heb het gevoel dat de juf/meester het niet } \\
\text { goed vindt als ik Turks praat.*** }\end{array}$ & .36 & -.16 & .34 \\
\hline $\begin{array}{l}\text { 4. Ik mag van de juf/meester in de klas geen } \\
\text { Turks praten met andere kinderen.** }\end{array}$ & .77 & -.31 & .04 \\
\hline $\begin{array}{l}\text { 7. Ik heb het gevoel dat het de juf/meester niet } \\
\text { uitmaakt of ik Turks of Nederlands spreek. }\end{array}$ & -.60 & .01 & -.04 \\
\hline $\begin{array}{l}\text { 8. Ik mag van de juf/meester op het schoolplein } \\
\text { geen Turks praten met andere kinderen.** }\end{array}$ & .84 & -.23 & .36 \\
\hline $\begin{array}{l}\text { 5. Ik heb het gevoel dat de juf/meester het } \\
\text { knap van mij vindt dat ik ook nog een andere } \\
\text { taal dan het Nederlands spreek. }\end{array}$ & -.14 & .37 & .03 \\
\hline $\begin{array}{l}\text { 6. De juf/meester geeft mij weleens een com- } \\
\text { pliment of pluim omdat ik ook Turks kan spre- } \\
\text { ken. }\end{array}$ & .09 & .91 & -.06 \\
\hline $\begin{array}{l}\text { 11. De juf/meester vraagt mij wel eens hoe je } \\
\text { iets in het Turks zegt. }\end{array}$ & -.12 & .27 & .02 \\
\hline $\begin{array}{l}\text { 1. De juf/meester heeft Turks met mij gespro- } \\
\text { ken, of met andere kinderen die ook Turks } \\
\text { spreken.*** }\end{array}$ & -.06 & .22 & -.30 \\
\hline
\end{tabular}




\begin{tabular}{l|c|c|c|}
\hline & \multicolumn{3}{|c}{ Factor } \\
\hline & $\begin{array}{c}\text { Tolerantie } \\
\text { thuistaal }\end{array}$ & $\begin{array}{c}\text { Appreciatie } \\
\text { thuistaal }\end{array}$ & $\begin{array}{c}\text { Stimuleren } \\
\text { Nederlands }\end{array}$ \\
\hline $\begin{array}{l}\text { 9. Ik heb het gevoel dat de juf/meester het } \\
\text { beter vindt dat ik thuis Nederlands spreek in } \\
\text { plaats van Turks. }\end{array}$ & .07 & .00 & .61 \\
$\begin{array}{l}\text { 10. Ik heb het gevoel dat de juf/meester het } \\
\text { belangrijk vindt dat ik altijd Nederlands spreek. }\end{array}$ & .10 & .11 & .72 \\
\hline \begin{tabular}{l} 
Percentage verklaarde variantie \\
\hline
\end{tabular} & 30.07 & 15.42 & 12.55 \\
\hline
\end{tabular}

*Voor Duits-tweetalige leerlingen werd 'Turks' vervangen door 'Duits'. **De itemscores werden gespiegeld voordat de schaalscores berekend werden, zodat een hogere score meer ervaren tolerantie betekende.***De itemscores werden gespiegeld voordat de schaalscores berekend warden, zodat een hogere score meer ervaren stimulatie van het Nederlands betekende.

\section{Analyse}

De analyses werden uitgevoerd in drie stappen. Eerst werden de prestaties van één- en tweetalige kinderen op EF-taken vergeleken met behulp van ANOVAs. Meer specifiek werden twee contrasten getoetst: het eerste om de prestaties van één- en tweetaligen te vergelijken, het tweede om een vergelijking tussen de twee tweetalige groepen te maken. Als maat van effectgrootte werd de $\eta^{2}$ berekend (Cohen, 1988). Ten tweede werden $t$ toetsen voor onafhankelijke steekproeven uitgevoerd, om de percepties van de twee groepen tweetalige leerlingen te vergelijken. Cohens $d$ (Cohen, 1988) werd daarbij gebruikt als maat voor de effectgrootte. Ten derde werden mediatie-analyses uitgevoerd om de vraag te beantwoorden of de mate waarin waardering voor de thuistaal werd ervaren, de verschillen in EF tussen de twee tweetalige groepen kon verklaren. In andere woorden: onderzocht werd of verschillen in ervaren waardering van de thuistaal de relatie tussen de thuistaal en EF-prestaties van het kind medieerde. Daarvoor werd een categorische variabele geconstrueerd, die informatie gaf over de thuistaal van het kind (Duits of Turks). Vervolgens werden lineaire regressieanalyses uitgevoerd volgens de stappen beschreven door Baron en Kenny (1986), om vast te stellen of het verwachte mediatieeffect bestond. Met de eerste regressieanalyse werd nagegaan of er een relatie bestond tussen de thuistaal en EF. De tweede werd uitgevoerd om inzicht te verkrijgen in de relatie tussen de thuistaal en de ervaren leerkrachtwaardering. De derde analyse had betrekking op de invloed van de ervaren waardering op de verschillende EF-processen. Om inzicht te krijgen in de mate waarin de thuistaal deze relatie kan verklaren, werd de thuistaal in de analyse betrokken. $R^{2}$ (Cohen, 1992) werd berekend als maat voor de effectgrootte. Sobel-testen (Sobel, 1982) werden uitgevoerd 
om te achterhalen of het mediatie-effect significant was. Het significantieniveau werd op .05 gesteld.

\section{Resultaten}

\section{Executieve functies}

Zoals de beschrijvende statistieken in Tabel 1 tonen, presteerden DuitsNederlandse kinderen beter op alle EF-taken, uitgezonderd de inhibitietaak. Ze hadden gemiddeld meer reeksen goed op zowel de Corsi Block Tapping-taak als de Digit Span-taak, bovendien waren ze sneller in de Faces-taak. Het eerste contrast liet zien dat er significante verschillen bestonden tussen één- en tweetalige kinderen in non-verbaal werkgeheugen $(t(68)=-2.22, p=.030)$ en in switching $(t(68)=2.11, p=.038)$ : tweetaligen presteerden beter op deze taken dan eentaligen. Beide effecten waren klein (respectievelijk $\eta^{2}=.07$ en $\eta^{2}=.09$ ). In inhibitie $(t(68)=-0.19, p=.466$ ), noch in verbaal werkgeheugen $(t(68)=-1.35, p=.181)$ waren er tussen tweetalige en eentalige leerlingen significante verschillen. De twee tweetalige groepen verschilden significant in verbaal werkgeheugen $(t(68)=3.12, p=$ .003): Duits-Nederlandse kinderen presteerden beter dan Turks-Nederlandse kinderen. Hierbij was sprake van een middelgroot effect $\left(\eta^{2}=.15\right)$.

\section{Intelligentie}

Er waren significante verschillen tussen de drie groepen in de scores op de Raven-test $(F(2,68)=11.76, p<.001$; zie Tabel 1$)$. Om na te gaan of deze verschillen invloed hadden op EF werden regressieanalyses uitgevoerd met de ruwe totaalscore op de Raven-test als onafhankelijke en EF-scores als afhankelijke variabelen. Intelligentie had een significant positief effect op non-verbaal $(b=0.10, S E=.03, p=.003)$ en verbaal werkgeheugen $(b=0.14$, $S E=.04, p<.001)$. Deze effecten waren respectievelijk klein $\left(R^{2}=.12\right)$ en middelgroot $\left(R^{2}=.17\right)$. Er werd geen significante relatie gevonden tussen intelligentie en switching of inhibitie $(p>.05)$. Vanwege de kleine groepen was het onderscheidend vermogen te gering. Reden om intelligentie niet in verdere analyses op te nemen.

\section{SES}

Verschillen in EF zouden kunnen samenhangen met verschillen in SES. Omdat statistische controle voor SES niet mogelijk was vanwege de (te) kleine groepen, werden post-hoc analyses uitgevoerd. Alle Duits-Nederlandse kinderen waren afkomstig uit een hoog sociaal-economisch milieu, 
waardoor voor deze groep geen analyses uitgevoerd konden worden. Voor de andere twee groepen werd er geen significante relatie gevonden tussen SES en EF $(p>.05)$. SES werd niet als controlevariabele meegenomen in de verdere regressieanalyses omdat dat het onderscheidend vermogen van de analyse zou doen verminderen.

\section{Ervaren leerkrachtwaardering van de thuistaal}

Uit de beschrijvende statistieken van de vragenlijsten, beschreven in Tabel 1, valt op te maken dat Duits-Nederlandse leerlingen niet alleen meer tolerantie en appreciatie van hun thuistaal ervoeren dan Turks-Nederlandse leerlingen, maar ook minder het gevoel hadden gestimuleerd te worden om Nederlands te gebruiken. Uit een $t$-toets voor onafhankelijke steekproeven bleek dat er inderdaad significante verschillen bestonden tussen de twee groepen in de mate waarin zij ervoeren dat hun leerkracht hun thuistaal tolereerde $(t(46)=5.41, p<.001, d=1.60)$, apprecieerde $(t(46)=$ 2.74, $p=.009, d=0.81)$, en hen stimuleerde Nederlands te spreken $(t(46)=$ -2.32, $p=.025, d=-0.68)$. De eerste twee effecten waren groot, het laatste middelgroot. Daarna werd nagegaan of de mate waarin tweetalige leerlingen ervoeren dat hun leerkracht hun thuistaal waardeerde, invloed had op hun EF. Uit de regressieanalyses bleek dat de ervaren tolerantie van de thuistaal significant gerelateerd was aan zowel het non-verbaal $(b=1.32$, $S E=0.45, p=.005)$ als het verbaal werkgeheugen $(b=1.23, S E=0.57, p=$ $.035)$. Beide effecten waren van middelmatige grootte $\left(R^{2}=.18\right.$ en $R^{2}=.12$, respectievelijk).

Geen van de andere sub-schalen bleek van significante invloed op switching of werkgeheugen ( $p$ 's > .05). Uit de daaropvolgende regressieanalyses bleek dat de ervaren waardering van de thuistaal van invloed was op de prestaties van de twee groepen tweetalige leerlingen op taken die het verbaal en non-verbaal werkgeheugen maten, maar niet op taken die switching of inhibitie vaststelden (zie Tabel 3 ). Het effect van ervaren tolerantie van de thuistaal op non-verbaal werkgeheugen was middelgroot $\left(R^{2}=.20\right)$. De Sobel-test was significant, hetgeen erop wijst dat verschillen in nonverbaal werkgeheugen tussen de twee tweetalige groepen gemedieerd werden door hun percepties van de mate waarin hun leerkracht hun thuistaal tolereerde. Er was echter enkel sprake van gedeeltelijke mediatie, aangezien er initieel geen significante verschillen waren tussen de twee groepen in non-verbaal werkgeheugen. Wel kan er gesproken worden van een indirecte relatie via de ervaren tolerantie voor gebruik van de thuistaal. De significante verschillen tussen de twee tweetalige groepen in verbaal werkgeheugen verdwenen nadat de sub-schalen van waardering als voorspellers 
in de analyse werden opgenomen. Geen van deze sub-schalen was echter significant gerelateerd aan het verbaal werkgeheugen. Derhalve kon geconcludeerd worden dat de leerkrachtwaardering van de thuistaal niet functioneerde als mediator voor de groepsverschillen in verbaal werkgeheugen.

Tabel 3 Lineaire regressieanalyses om de mediërende effecten van ervaren thuistaalwaardering op de relatie tussen thuistaal en EF te achterhalen

\begin{tabular}{|c|c|c|c|c|c|c|c|c|c|c|c|c|}
\hline & \multicolumn{2}{|c|}{$\begin{array}{c}\text { Effect } \\
\text { thuistaal }\end{array}$} & \multicolumn{2}{|c|}{$\begin{array}{c}\text { Partieel effect } \\
\text { tolerantie } \\
\text { thuistaal }\end{array}$} & \multicolumn{2}{|c|}{$\begin{array}{c}\text { Partieel effect } \\
\text { appreciatie } \\
\text { thuistaal }\end{array}$} & \multicolumn{2}{|c|}{$\begin{array}{c}\text { Partieel effect } \\
\text { stimuleren Ne- } \\
\text { derlands }\end{array}$} & \multicolumn{2}{|c|}{$\begin{array}{c}\text { Partieel effect } \\
\text { thuistaal }\end{array}$} & \multicolumn{2}{|c|}{ Sobel-test } \\
\hline & $b$ & SE & $b$ & SE & $b$ & SE & $b$ & SE & $b$ & SE & $b$ & SE \\
\hline $\begin{array}{l}\text { Non-verbaal } \\
\text { werkgeheugen }\end{array}$ & -0.15 & 0.32 & $1.61^{*}$ & 0.53 & -0.06 & 0.51 & -0.96 & 0.58 & 0.40 & 0.40 & $-2.61^{*}$ & 0.28 \\
\hline $\begin{array}{l}\text { Verbaal werk- } \\
\text { geheugen }\end{array}$ & $-1.09^{*}$ & 0.36 & 0.56 & 0.65 & -0.26 & 0.62 & 0.30 & 0.71 & -0.95 & 0.49 & - & - \\
\hline Switching & 26.23 & 18.61 & 24.83 & 32.15 & 42.65 & 30.96 & 55.71 & 35.03 & 15.29 & 24.33 & - & - \\
\hline Inhibitie & -48.70 & 41.55 & -30.80 & 78.77 & -56.54 & 72.03 & 72.13 & 77.49 & -87.61 & 54.81 & - & - \\
\hline
\end{tabular}

${ }^{*} p<.05$.

\section{Discussie}

In dit onderzoek werd nagegaan of tweetalige basisschoolleerlingen met Turks dan wel Duits als thuistaal verschilden in hun percepties van de mate waarin hun leerkrachten hun thuistaal waardeerden, en of deze percepties invloed hadden op de ontwikkeling van hun executieve functies (EF). Gevonden werd dat Turks-Nederlandse kinderen minder waardering van hun thuistaal ervoeren dan Duits-Nederlandse kinderen, en dat deze ervaringen gerelateerd waren aan het non-verbaal werkgeheugen. DuitsNederlands tweetalige leerlingen lijken meer te profiteren van het feit dat zij tweetalig zijn dan hun Turks-Nederlandse leeftijdsgenootjes, en dit lijkt gedeeltelijk gerelateerd te zijn aan de mate waarin hun leerkracht hun thuistaal waardeert.

De bevindingen van dit onderzoek - dat tweetalige kinderen beter presteren dan eentalige kinderen op non-verbaal werkgeheugen en switching-taken - komen overeen met eerder uitgevoerd onderzoek (Bialystok \& Viswanathan, 2009; Morales et al., 2013). Verondersteld wordt dat het beheersen van en het wisselen tussen twee talen resulteert in beter ontwikkelde switching-vaardigheden (Green, 1998), alsmede in een meer effi- 
ciënte manier van informatieverwerking door het non-verbaal werkgeheugen (Adesope et al., 2010).

In tegenstelling tot eerder onderzoek (Bialystok \& Viswanathan, 20o9; Morales et al., 2013), werden in dit onderzoek echter geen voordelen gevonden voor tweetalige leerlingen in inhibitie of verbaal werkgeheugen. Tot op zekere hoogte zou de opzet van het onderzoek daar debet aan kunnen zijn. De taak die de kinderen voorgelegd kregen om hun vermogen tot inhibitie vast te stellen, leek te moeilijk, afgaande op het relatief hoge foutenpercentage van $9.0 \%$. Niettemin zijn de resultaten van onze studie in overeenstemming met die van Antón et al. (2014), die in hun onderzoek bij kinderen van dezelfde leeftijd een vergelijkbare taak gebruikten om inhibitie te meten. Onze bevindingen op het gebied van verbaal werkgeheugen zijn eveneens in lijn met eerder onderzoek. Luo, Craik, Moreno en Bialystok (2013) stelden vast dat tweetalige kinderen in het nadeel zijn waar het om verbale taken gaat en het genoten voordeel in werkgeheugen voornamelijk betrekking heeft op het non-verbale domein. Bovendien zouden tweetalige kinderen voornamelijk dán in het voordeel zijn wanneer de taak betrekking heeft op meerdere EF-domeinen (Morales et al., 2013). Daarom zou een mogelijke verklaring voor het gevonden nulresultaat weleens kunnen zijn dat de Digit Span-taak enkel betrekking heeft op het verbaal werkgeheugen en niet andere EF-componenten betreft.

Zoals eerder opgemerkt, bleek dat Duits-Nederlandse leerlingen meer leerkrachtwaardering van hun thuistaal ervoeren dan Turks-Nederlandse leerlingen. Dit gegeven staaft de stellingname dat ook in de sociolinguïstische context van de klas sommige talen minder waardering genieten dan andere, hetgeen met name opgaat voor talen die gesproken worden door kinderen uit etnische minderheidsgroeperingen (Extra \& Yağmur, 2004). Zoals in eerder onderzoek (Pulinx et al., 2015), dringt ook in dit onderzoek de conclusie zich op dat leerkrachten, althans degenen in onze steekproef, handelen in navolging van het overheidsbeleid dat het gebruik van etnische minderheidstalen op school ontmoedigt (Kuiken \& Van der Linden, 2013).

Tot op zekere hoogte werden de voorspelde voordelen van tweetaligheid op school door de resultaten van dit onderzoek bevestigd: verschillen in de mate waarin leerkrachten de thuistaal waarderen, en met name de mate van tolerantie, bleken gerelateerd aan verschillen tussen de twee tweetalige groepen op het gebied van werkgeheugen. Hoe meer kinderen het gevoel hadden dat de leraar hun thuistaal tolereerde, des te beter zij presteerden op de non-verbale werkgeheugentaak. Een verklaring voor deze bevinding kan zijn dat kinderen die het gevoel hebben dat hun leer- 
krachten hun thuistaal tolereren, les krijgen in een omgeving waarin hen de mogelijkheid geboden wordt om zich zowel van hun thuistaal als van het Nederlands te bedienen. In een dergelijke omgeving kunnen zij beide talen gebruiken, en naar believen tussen die twee wisselen. Dit vraagt constante onderdrukking van één taal, en het bedwingen van linguïstische competitie tussen woorden in beide talen hetgeen de ontwikkeling van hun EF ten goede komt.

Dit onderzoek kent een aantal beperkingen die het beletten sterke conclusies te trekken. Ten eerste werd er gebruik gemaakt van een specifieke wervingsprocedure om afhankelijkheid van de data te voorkomen. Daarbij golden restricties betreffende de leeftijd en de specifieke thuistaal van de participanten. Bovendien werd elk kind individueel getest en waren we afhankelijk van de welwillendheid van kinderen en ouders om aan het onderzoek deel te nemen. De werving en uitvoering van het onderzoek waren daarom bijzonder tijdsintensief, hetgeen resulteerde in relatief kleine onderzoeksgroepen met een beperkte variëteit naar sociaal-economisch milieu. Grootschaliger onderzoek met groepen die meer divers naar sociaal-economische status zijn samengesteld, is noodzakelijk om na te kunnen gaan hoe robuust de resultaten van het huidige onderzoek zijn.

Omdat de focus van dit onderzoek lag op de leerlingpercepties van de mate waarin hun leerkrachten hun thuistaal waardeerden, kon het daadwerkelijke gebruik van de thuistaal in de klas niet geregistreerd worden. Door observaties in de klas zou in toekomstig onderzoek nagegaan kunnen worden in welke mate leerlingen ook werkelijk gewoon zijn zich op school van twee talen te bedienen en deze ook afwisselend gebruiken, en welke invloed dit op de ontwikkeling van hun EF heeft.

In dit onderzoek werd aangetoond dat tweetalige kinderen cognitieve voordelen vertonen ten opzichte van eentalige kinderen. Er werd echter ook aangetoond dat deze voordelen niet los gezien kunnen worden van de sociolinguïstische (klas)context. Ondanks de vermelde limitaties en het exploratieve karakter van dit onderzoek, leveren de resultaten bewijs voor de hypothese dat de sociolinguïstische context van invloed is op de voordelen die tweetaligheid met zich mee kan brengen.

De resultaten van dit onderzoek hebben implicaties voor het onderwijsbeleid en de onderwijspraktijk. In Nederland kennen veel scholen tegenwoordig een 'alleen-Nederlands-beleid' (Frijns, 2014). Dit impliceert dat kinderen belemmerd worden om hun tweetaligheid tentoon te spreiden en optimaal te benutten. De mogelijkheden om de cognitieve voordelen van tweetaligheid te ontwikkelen worden daarmee beperkt. Het spreken van een andere taal zou, aldus de Nederlandse overheid, de integratie 
hinderen (Kuiken \& Van der Linden, 2014), en het gebruik van het Nederlands belemmeren, wat weer resulteert in een achterstand in het Nederlands (Leseman, 2000). Met het huidige onderzoek werd echter aangetoond dat een sociolinguïstische context waarin talen gewaardeerd worden juist positieve gevolgen kan hebben; de EF worden er immers door bevorderd. Als toekomstig onderzoek aantoont dat er sprake is van een causale relatie, zouden overheidsinstanties hun restrictieve beleid met betrekking tot het gebruik van minderheidstalen op school moeten herzien.

Daarnaast zouden leerkrachten bewust gemaakt moeten worden van de voordelen die tweetaligheid biedt, alsmede van de consequenties die hun waardering van de verschillende talen voor de cognitie van hun leerlingen heeft. Lerarenopleiders kunnen in dit proces een belangrijke rol spelen, aangezien zij (toekomstige) leraren kunnen voorzien van de kennis en vaardigheden die nodig zijn om cultuurresponsiviteit te bevorderen (Brown, 2007; Gay, 2002; Villegas \& Lucas, 2007).

Deze studie heeft bovendien implicaties voor wetenschappelijk onderzoek. In dit onderzoek werden sociolinguïstische theorieën gecombineerd met een cognitief-psychologische benadering. De resultaten waaruit blijkt dat de cognitief-psychologische vaardigheden van tweetalige kinderen beter geïnterpreteerd kunnen worden met inachtneming van een sociolinguïstisch onderzoeksperspectief, tonen aan hoe belangrijk het is om een multidisciplinaire aanpak te hanteren wanneer er onderzoek wordt gedaan naar de voordelen van tweetaligheid.

\section{Referenties}

Adesope, O. O., Lavin, T., Thompson, T., \& Ungerleider, C. (2010). A systematic review and metaanalysis of the cognitive correlates of bilingualism. Review of Educational Research, $80(2)$, 207-245.

Agirdag, O. (2010). Exploring bilingualism in a monolingual school system: Insights from Turkish and native pupils from Belgian schools. British Journal of Sociology of Education, $3^{1}(3), 207-$ 321.

Agirdag, O., Jordens, K., \& Van Houtte, M. (2014). Speaking Turkish in Belgian primary schools: Teacher beliefs versus effective consequences. Bilig, 7o(3), 7-28.

Antón, E., Duñabeitia, J. A., Estévez, A., Hernández, J. A., Castillo, A., Fuentes, L. J., ... Carreiras, M. (2014). Is there a bilingual advantage in the ANT task? Evidence from children. Frontiers in Psychology, 5(398), 1-12.

Appel, R., \& Muysken, P. (2005). Language contact and bilingualism. Amsterdam: Amsterdam University Press.

Atwill, K., Blanchard, J., Christie, J., Gorin, J. S., \& García, H. S. (2010). English-language learners: Implications of limited vocabulary for cross-language transfer of phonemic awareness with kindergartners. Journal of Hispanic Higher Education, 9(2), 104-129. 
Baron, R. M., \& Kenny, D. A. (1986). The moderator-mediator variable distinction in social psychological research: Conceptual, strategic, and statistical considerations. Journal of Personality and Social Psychology, 52, 844-863.

Bialystok, E. (2009). Bilingualism: The good, the bad and the indifferent. Bilingualism: Language and Cognition, 12(1), 3-11.

Bialystok, E., \& Viswanathan, M. (2009). Components of executive control with advantages for bilingual children in two cultures. Cognition, 112(3), 494-500.

Blair, C., \& Peters Razza, R. (2007). Relating effortful control, executive function, and false belief understanding to emerging math and literacy ability in kindergarten. Child Development, 78 (2), 647-663.

Brown, M. R. (2007). Educating all pupils: Creating culturally responsive teachers, classrooms and schools. Intervention in School and Clinic, 43, 57-62.

Carlson, S. M., \& Meltzoff, A. N. (2008). Bilingual experience and executive functioning in young children. Developmental Science, $n(2), 282-298$.

Chun, H., \& Dickson, G. (2011). A psychoecological model of academic performance among Hispanic adolescents. Journal of Youth and Adolescence, 4o(12), 1581-1594.

Cohen, J. (1988). Statistical power analysis for the behavioral sciences (2nd edn). Hillsdale, NJ: Lawrence Earlbaum Associates.

Cohen, J. (1992). A power primer. Psychological Bulletin, 112(1), 155-159.

Diamond, A. (2013). Executive functions. Annual Review of Psychology, 64, 135-168.

Diamond, A., Barnett, W. S., Thomas, J., \& Munro, S. (2007). Preschool program improves cognitive control, Science, $318,1387-1388$.

Eisenchlas, S. A., Schalley, A. C., \& Guillemin, D. (2013). The importance of literacy in the home language. SAGE Open, 3(4), 1-14.

Extra, G., \& Yağmur, K. (2004). Meertaligheid in multicultureel Europa: De status van immigrantentalen thuis en op school. Levende Talen Tijdschrift, 5(1), 13-18.

Frijns, C. (2014). Ont-armen of omarmen? Over onze omgang met (meer) talen op school. Meer Taal, 3(1), 5-7.

Garon, N., Bryson, S. E., \& Smith, I. M. (2008). Executive function in preschoolers: A review using an integrative framework. Psychological Bulletin, 134(1), 31-60.

Gay, G. (2002). Preparing for culturally responsive teaching. Journal of Teacher Education, 53, 106116.

Green, D. W. (1998). Mental control of the bilingual lexico-semantic system. Bilingualism: Language and Cognition, $1,67-81$.

Kort, W., Schittekatte, M., Dekker, P. H., Verhaeghe, P., Compaan, E. L., Bosmans, M., \& Vermeir, G. (2005). WISC-III NL Wechsler Intelligence Scale for Children. Derde Editie NL. Handleiding en Verantwoording. Amsterdam: Harcourt Test Publishers/Nederlands Instituut voor Psychologen.

Kuiken, F., \& Van der Linden, E. (2014). Language policy and language education in the Netherlands and Romania. Dutch Journal of Applied Linguistics, 2(2), 205-223.

Lee, J. S., \& Oxelson, E. (2006). "It's not my job": K-12 teacher attitudes toward pupil's heritage language maintenance. Bilingual Research Journal: The Journal of the National Association for Bilingual Education, 3o(2), 453-477.

Leseman, P. P. M. (2000). Bilingual vocabulary development of Turkish preschoolers in the Netherlands. Journal of Multilingual and Multicultural Development, 21(2), 93-112.

Luo, L., Craik, F. I. M., Moreno, S., \& Bialystok, E. (2013). Bilingualism interacts with domain in a WM task: Evidence from aging. Psychology and Aging, 28(1), 28-34.

Miyake, A., Friedman, N. P., Emerson, M. J., Witzki, A. H., Howerter, A., \& Wager, T. D. (200o). The 
unity and diversity of executive functions and their contributions to complex "frontal lobe" tasks: A latent variable analysis. Cognitive Psychology, 41, 49-100.

Moffitt, T. E., Arseneault, L., Belsky, D., Dickson, N., Hancox, R. J., Harrington, H., ... Caspi, A. (2011). A gradient of childhood self-control predicts health, wealth, and public safety. Proceedings of the National Academy of Sciences, 108(7), 2693-2698.

Morales, J., Calvo, A., \& Bialystok, E. (2013). Working memory development in monolingual and bilingual children. Journal of Experimental Child Psychology, 114(2), 187-202.

Pulinx, R., Van Avermaet, P., \& Agirdag, O. (2015). Silencing linguistic diversity: the extent, the determinants and consequences of the monolingual beliefs of Flemish teachers. International Journal of Bilingual Education and Bilingualism, 13670050.2015.1102860

Raven, J. C., Court, J. H., \& Raven, J. C. (1990). Manual for Raven's Progressive Matrices and Vocabulary Scales - section 2: Coloured Progressive Matrices. Oxford: Oxford Psychology Press.

Sobel, M. E. (1982). Asymptotic confidence intervals for indirect effects in structural equation models. Sociological Methodology, 13, 290-312.

St Clair-Thompson, H. L., \& Gathercole, S. E. (2006). Executive functions and achievements in school: Shifting, updating, inhibition, and working memory. The Quarterly Journal of Experimental Psychology, 59(4), 745-759.

Vandierendonck, A., Kemps, E., Fastame, M. C., \& Szmalec, A. (2004). Working memory components of the Corsi blocks task. British Journal of Psychology, 95(1), 57-79.

Van Gaalen, R., \& De Vos, A. (2011). Sociaaleconomische positie van ouders en kinderen naar herkomst. Bevolkingstrends, 22-27.

Villegas, A. M., \& Lucas, T. (2007). The culturally responsive teacher. Educational Leadership, 64 (6), $28-33$.

\section{Over de auteurs}

Claire Goriot is als promovenda werkzaam aan de afdeling Taalwetenschap van het Centre for Language Studies van de Radboud Universiteit, Nijmegen. Correspondentieadres: c.goriot@let.ru.nl

Joep Bakker is, ondanks zijn pensioengerechtigde leeftijd nog altijd werkzaam als docent bij de afdeling PWO van de Radboud Universiteit en is als associate member verbonden aan het Behavioural Science Insitute.

Eddie Denessen is als universitair hoofddocent verbonden aan het Behavioural Science Institute van de Radboud Universiteit, Nijmegen.

Mienke Droop is universitair docent Onderwijskunde bij het Behavioural Science Institute van de Radboud Universiteit, Nijmegen. 
